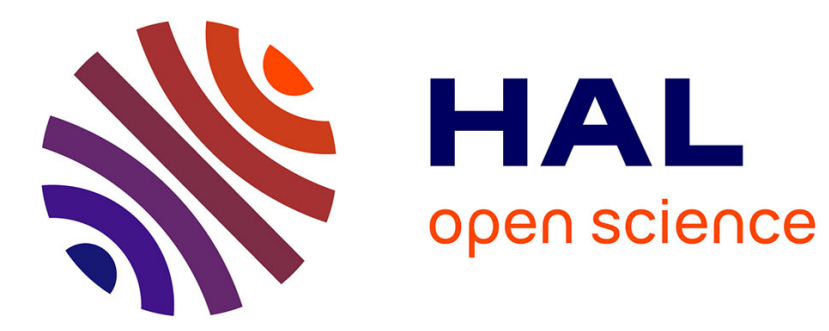

\title{
Community treatment orders for patients with psychosis
}

Florian Naudet, Mohamed El Sanharawi

\section{To cite this version:}

Florian Naudet, Mohamed El Sanharawi. Community treatment orders for patients with psychosis.

The Lancet, 2013, 382 (9891), pp.501-502. 10.1016/S0140-6736(13)61705-5 . hal-00994788

\section{HAL Id: hal-00994788 \\ https://hal-univ-rennes1.archives-ouvertes.fr/hal-00994788}

Submitted on 14 Nov 2018

HAL is a multi-disciplinary open access archive for the deposit and dissemination of scientific research documents, whether they are published or not. The documents may come from teaching and research institutions in France or abroad, or from public or private research centers.
L'archive ouverte pluridisciplinaire HAL, est destinée au dépôt et à la diffusion de documents scientifiques de niveau recherche, publiés ou non, émanant des établissements d'enseignement et de recherche français ou étrangers, des laboratoires publics ou privés. 


\section{Community treatment orders for patients with psychosis}

Florian NAUDET, MD; Centre d'Investigation Clinique CIC-P INSERM 0203, Hôpital de Pontchaillou, Centre Hospitalier Universitaire de Rennes \& Université de Rennes 1, Rennes, France

Mohamed EL SANHARAWI, MD; INSERM, UMRS 872, Centre de Recherche des Cordeliers, Team 17, Université Pierre et Marie Curie - Paris 6, Paris, France

\section{Corresponding author :}

Florian Naudet

Centre d’Investigation Clinique, Inserm 0203, Unité de Pharmacologie Clinique, Hôpital de Pontchaillou, 2 rue Henri le Guilloux, 35033 Rennes cedex 9.

Tél : 02.99.28.37.15

Email : floriannaudet@gmail.com

249 words 
Psychiatric care is often organized upon a legal framework which is not validated from a scientific perspective. To overcome this state of the art, Burns et al. tested whether Community Treatment Orders (CTOs) reduce admissions compared with use of Section 17 leave and found no support in terms of any reduction in overall hospital admission (1). However, despite there was no significant evidence of superiority, it does not mean that the two interventions are equivalent. For ethical, practical, and legal reasons, $21 \%$ of the patients in the CTOs group and $24 \%$ of the patients in the Section 17 leave group were switched to the other intervention. When such protocol violations are the rule rather than the exception, intention to treat analysis (ITT) is too much conservative to say that no difference exists between the two interventions because the two groups become very similar. For this reason, authors have performed a per-protocol analysis (PP) which gave similar results that the ITT (they did not present results of this analysis). Nevertheless, such analysis suffers from a dramatic loss of power with a type II error $(\beta)$ of $33 \%$ under the hypotheses stated in the paper.

The obvious next step does not need new data acquisition. It consists of performing an equivalence meta-analysis based on the three available randomised controlled trials (1-3). Since such analysis need to focus upon both analyses sets (ITT and PP), it is then necessary that authors make available the results of their per-protocol analysis.

\section{Competing interests}

There are no conflicts of interest regarding this letter.

\section{References}

1- Tom Burns, Jorun Rugkåsa, Andrew Molodynski, John Dawson, Ksenija Yeeles, Maria Vazquez-Montes, Merryn Voysey, Julia Sinclair, Stefan Priebe. Community treatment orders 
for patients with psychosis (OCTET): a randomised controlled trial. Lancet 26 March 2013. doi:10.1016/S0140-6736(13)60107-5. (Early Online Publication)

2- Steadman HJ, Gounis K, Dennis D, et al. Assessing the New York. City involuntary outpatient commitment pilot program. Psychiatr Serv 2001; 52: 330-36.

3- Swartz MS, Swanson JW, Wagner HR, Burns BJ, Hiday VA, Borum R. Can involuntary outpatient commitment reduce hospital recidivism?: fi ndings from a randomized trial with severely mentally ill individuals. Am J Psychiatry 1999; 156: 1968-75. 